$\mathbf{R}_{\text {eSearch }} \mathbf{P}_{\text {APER }} \longrightarrow$ FOOD SCIENCE

\title{
Nutritional contribution of mid day meal in daily energy and protein intake of primary school children in Kanpur district
}

\author{
Nidhee Sachan and Rashmi Singh
}

\begin{abstract}
The concept of mid day meal has long history in India. In 1925, a mid day meal programme was introduced for children belonging to poor socio-economic status in Madras corporation area. It has been reported that mid day meal has catered to the nutritional needs of school children in both urban and rural areas. The present study was, therefore, an attempt to evaluate the nutritional contribution of mid day meal to the actual daily nutrient intake of primary school children. To attain the objective of the study, two hundred school children in the age group 6-12 years were selected from urban and rural areas using purposive random sampling. Hundred primary school children were selected from both the areas. Results of the survey conducted in 6 primary schools of Kanpur revealed that cyclic menu for six days was being followed by the schools undertaken in the study. It was found that Tahari and milk was the most liked (59\%) meal,followed by Dal chawal (45\%), Dal roti (35\%), Roti sabji (31\%) and least preferred meal was Sabji chawal (30\%). The energy content of six days menu varied from 350-442 Kcal which is below the recommended norms of $450 \mathrm{Kcal}$.
\end{abstract}

Key Words : Mid day meal, Protein intake, Primary school children, Health, Malnutrition

How to cite this article : Sachan, Nidhee and Singh, Rashmi (2017). Nutritional contribution of mid day meal in daily energy and protein intake of primary school children in Kanpur district. Food Sci. Res. J., 8(2): 203-206, DOI : 10.15740/HAS/FSRJ/8.2/203206. 